\title{
DIE GELOFTEKERK.
}

\section{Woord vooraf.}

In die afgelope paar jaar was daar heelwat beroering in die land omdat beweer is dat die gelofte wat die Voortrekkers in Desember 1838 aan God gedoen het om na 'n eventuele oorwinning 'n kerk te bou tot eer van sy naam en uit dankbaarheid dat $\mathrm{Hy}$ hulle gebede verhoor het, nooit uitgevoer is nie, en dat die kerk wat gebou is en wat tans as die Voortrekkermuseum bekend staan, nie die egte gelofte kerk is nie. Die Natalse Provinsiale Raad het selfs 'n ordinansie gepasseer waarin die stadsraad van Pietermaritzburg die reg gegee word om 'n seker stuk grond wat die Voortrekkers vir die bou van die gelofte kerk sou gereserveer het, aan die kerkraad van die Ned. Geref. Gemeente aldaar te skenk, sodat die geloftekerk nou eindelik gebou kan word. Dit het heelwat beroering gebring, want dit sou skokkend wees as dit sou blyk dat die Voortrekkers ontrou was en en die gedane belofte nie uitgevoer nie.

Die Sentrale Volksmonumentekomitee het dit dan ook nodig geag om die saak grondig te laat ondersoek en dit aan professor $\mathrm{H}$. B. Thom van Stellenbosh en aan myself opgedra om 'n historiese ondersoek in te stel. Hierdie ondersoek is onafhanklik van mekaar gedoen, en die bevindings was dieselfde: die huidige Voortrekkermuseum was deur die Voortrekkers as die geloftekerk bedoel. Op die jongste vergadering van die Volksmonumentekomitee is besluit dat die rapporte gepubliseer kan word, en daarom word my rapport hier afgedruk.

Rapport oor die Geloftekerk deur Prof. Dr. S. P. Engelbrecht.

As die belangrikste gegewens oor die totstandkoming van die Voortrekkergelofte kan die volgende geld:

1. Die joernaal van Bantjies $\left.{ }^{1}\right)$ :

Des Zondags morgens, voordat de Godsdienst begon, liet de Hoofd-Kommandant degenen die de Godsdienst zouden verrigten. by malkander komen, en verzocht hen, met de gemeente te spreken, dat zij allen volyverig in geest en in waarheid, tot God mogt bidden, om zijne hulp en bijstand in het slaan tegen den

1) G. S. Preller: Hoe ons aan Dingaansdag kom (herdruk uit De Zuid Afrikaan) bls. 12: John Bird: The Annals of Natal, Vol. I, pr. 445. 
vyand; dat hij aan den Almagtigen een gelofte doen wilde, (indien allen wel willen), - „om zoo de Heere ons de overwinning geven mogt, een $\mathrm{Huis}$ tot zijns grooten Naams gedagtenis te stichten alwaar het Hem zal behagen," - en dat zij ook moesten afsmeken, de hulp en bijstand van God, om deze gelofte zeker te kunnen volbrengen, en dat wij den dag der overwinning, in een boek zullen aanteekenen, om dezelve bekend te maken, zelfs aan onze laatste nageslachten, opdat het ter Eere van God gevierd mag worden.

\section{Die brief van Generaal A. W. J. Pretorius van die Hoofstad} van Dingaan op 23 Desember $\left.1838^{2}\right)$ :

Verder moet $i k$ u melden, dat wij besloten hebben om den dag onzer overwinning, zijnde Zondag den 16 December, onder ons gansche nageslacht te doen bekend worden, en dat wij het aan den Heer willen toewyden en vieren met dankzeggingen, zoo als wij, vo sr aot wij tegen den vijand streden, in het openbaar beloofd hebben, zoo ook, dat zoo wij de overwinning verkregen mogen, wij den Heere tot zijns naams gedachtenis een huis stichten zullen alwaar $\mathrm{Hij}_{\mathrm{ij}}$ ons zulks aanwijzen zal; welke geloften wij nu hopen te betalen met de hulp des Heeren, nu $\mathrm{Hij}$ ons gezegend en onze gebeden verhoord heeft.

3. Die opstel van Dewald Pretorius in Maart 1862, wat die volgende oor die gelofte meedeel ${ }^{3}$ ):

En het herinnert mij alsof het vandaag gebeurde, hetgeen daar toen plaats vond, dat vóór het begin van de godsdienst, de Kommandant-Generaal, die het bestuur van het kommando had, A. W. J. Pretorius, aan den Heer Celliers vraagt om eene belofte aan den Heer onzen God te doen, dat, als de Heer de overwinning aan onzen kant geeft, die dag als een bededag alle jaren gevierd zal worden, en dat in het land, dat nu eene woestyn en een moordenaarskuil is, kerken en scholen gebouwd zullen worden tot Gods eer. En dat de Heer Celliers tot den kommandant zeide: Oude Broeder, ik ben bevreesd, God is een jaloersch God. Wij zullen den dag verwaarloozen en wij zullen met dubbele slagen geslagen worden. Hij begint daarop met zijne godsdienst en onder het houden van de dienst, wordt hij zoo gesterkt dat hij het waagt te doen en het bovenstaande belooft en vraagt

2) De Zuid Afrikaan 16 Feb. 1839, Het Nederduitsch Zuid-Afrikaansch Tijdschrift 1839 , bls. 155 .

3) Herinnering aan de merkwaardige verlossing der Afrikaansche Immigranten op Zondag 16 December 1838 by Bloedrivier. Gedrukt by P. Davis. Zn. P.M. Burg 1865. I herdie vandag baie seldsame brosjure is in 1865 deur ds. P. Huet die Scriba van die Natalse Ring uitgegee na aanleiding van die besluit van die Ring op 20 Okt. 1864 om 16 Desember as 'n dankdag te vier. 
dat de Heere het hart van onzen vyand als water make en dat $z i j$ in zeven en meer dan zeven deelen van ons mogen aftrekken.

4. Die joernaal van Sarel Cilliers wat hy in 1870 opgestel het en waarin die volgende voorkom ${ }^{4}$ ):

De heer Andries Pretorius was onze gekozene Generaal, op deze commando, hij sprak met mij ook ik met hem, over de belofte die die Bijbel heilige heb gedaan, dat ook wij de Heere een belofte moeten doen, als de Heere ons de Overwinning, tegen onze Vijand zoude geven, dat wij dan die dag als een „sabbath elk jaar zoude heiligen, maar ik stelde voor wat David zegt, doet belofte maar betaald zijde Heer, het is beter dat wij niet beloof, als dat wij beloofd en niet betaal, het was dan zijne begeerte, dat wij tezamen Hem een belofte zoude doen, daar was noch een deel menschen, ook een Commandant die niet bij ons was. Ik zeide aan hem dat het uitstel moeten hebben totdat Cobus Wys, tegenwoordig was, hij kwam aan Tugela bij ons, en wij sprak toen met hem, en het was toen ook zijne begeerte, dat het gedaan moet worden, ook de Veldcornetten, toen kwamen wij tot de besluit, dat wij de Heere, onze God eene belofte pligtig zoude doen, als de Heere met ons zal gaan, en dat $\mathrm{Hij}_{\mathrm{j}}$ onzen Vijand in onzen handen zoude geven, dat wij de dag in elk jaar de Heer zoude "heiligen" en zoo door brengen als een Sabbathdag.

As ons hierdie vier stukke met mekaar vergelyk dan val dit op dat al vier ooreenstem dat beloof is om die dag van die oorwinning jaarliks op godsdienstige wyse as dankdag te vier. Verder, dat alleen Bantjies en A. W. J. Pretorius melding maak dat beloof is dat hulle as die oorwinning behaal is tot gedagtenis vir God 'n "huis" sal stig, maar dat hulle nog nie weet waar hulle dit sou doen nie. Dat Dewald Pretorius vermeld dat beloof is "kerken en scholen" tot Gods eer te bou. Dat Sarel Cilliers die bou van 'n kerk of kerke glad nie vermeld nie.

Ons neem aan dat beloof is om vir God 'n huis te bou, soos Bantjies en A. W. J. Pretorius vermeld. Die eerste Voortrekkers het reeds in 1836 die Oranjerivier oorgetrek, maar nêrens was daar 'n kerkgebou nie. Nou word beloof dat in kerk gebou sal word, m.a.w. as die mag van die swart barbare gebreek word, sal gesorg word dat van die land 'n christenland gemaak sal word, soos dan ook geinterpreteer deur Dewald Pretorius, toe hy in 1862 geskryf het dat beloof is om in die woesternye, ,kerken en scholen" te bou. Ook val dit op dat én Bantjies én A. W. J. Pretorius duidelik sê dat hul nog

4) H. J. Hofstede: Geschiedenis van den Oranje Vrijstaat, 1876, bls. 57. 
nie weet waat die huis gebou sal word nie. Soiets as ",geloftegrond" het dan ook nooit bestaan nie.

Een ding staan ook vas: met die gelofte het die Voortrekkers nimmer bedoel om 'n monumentele kerkgebou, 'n soort monument, te bou nie. Die bedehuise wat hulle in die Kaapkolonie geken het, was alger nederige geboue met grasdakke sonder torings, en die meeste het nie eers banke in gehad nie. Die enigste sierlike kerkgebou in die Kaapkolonie wat 'n toring gehad het, was die kerk in Kaapstad, en hoeveel van hulle het die kerk van Kaapstad wat in 1836 afgebreek is en eers in 1841 deur die teenswoordige gebou vervang is, gesien? Sierlike en grandieuse kerkgeboue in die hedendaagse sin van die woord, het hulle nie geken nie. Selfs in 1866 toe die hedendaagse kerkgebou van Potchefstroom ingewy is, het dit met sy grasdak en die ontbreking van alle sierlikheid tog as die mooiste gebou in Transvaal gegeld.

Op 8 Februarie 1837 is die eerste kerkraadslede gekies, en hulle het reeds by Vetrivier (Winburg) op 19 Mei 1837 'n oproep gedoen om 'n kerk te bou, maar deur die trek na Natal het daar niks van gekom nie. Aan die einde van 1838 was daar 'n groot laer aan die Boesmansrand, en na die oorwinning op 16 Desember is hier 'n dorp aangelê met die naam van Pieter Martizburg, en reeds op 21 Maart het Greneraal Pretorius hiervan geskryf $f^{5}$ ):

Op 13 Mei 1839 het J. J. Burger en J. S. Maritz 'n brief aan 'n viertal Kaapse predikante geskryf en om 'n predikant gevra, en o.a. daarin gesê dat dit altyd hul voorneme was om wanneer hulle rus gevind het ${ }^{6}$ )

Aan den God onzen vaderen een huis te willen bouwen.

Op 20 Mei 1839 word uit Natal berig dat die mense nog in laers $\left.\operatorname{staan}^{7}\right)$

van alle kanten met palen omringd welke tot eene verschansing dienen ... Het gansche volk verlangt eenen Leeraar, en is voornemens aan de Boschesmans Rand, de plaats waar de kolonie gesticht zal worden, eene kerk te bouwen. Met heeft reeds, terwijl wij ons aldaar bevonden, eene inteekingslijst geopend, en binnen den tijd van een half uur was er over de $£ 300$ ingeteekend.

In hierdie brief word ook vermeld dat Erasmus Smit Sondae godsdiens hou.

5) Ned. Zuid Afr. Tijdschrift 1839, bls. 239.

B) A. Dreyer: Die Kaapse Kerk en die Groot Trek, bls. 15

7) Ned. Zuid. Afri. Tijdschrift 1839, bls. 320. 
In 'n brief van J. S. Maritz aan Generaal Pretorius op 29 Mei 1839 maak hy melding van $\mathrm{die}^{8}$ )

Schoone voornemens van eerlang een schoone kerk te zien bouwen.

En op 13 Junie 1839 skryf Adv. C. J. Brand uit Kaapstad aan Pretorius dat hy daar ' $n$ intekenlys geopen het ${ }^{9}$ )

tot bijdragen van den opbouwen des tempels, welke gij den Heere hebt beloofd.

Op 7 September 1839 het die kerkraad 'n versoekskrif oor die bou van die kerk aan die Volksraad gestuur, waarop die Raad vier persone as "gecommiteerdes" benoem het, d.w.s. persone wat die saak moes aanpak. Ons kan met sekerheid aanneem dat daar intussen "n voorlopige kerk daargestel is, "n „rietkerk" soos die vrou van Erasmus Smit dit in haar dagboek noem, en wat deur Landdros J. P. Zietsman in 'n brief aan die Volksraad op 31 Januarie 1840 'n ",kerkhuis" genoem word. Sulke rietkerke het mens nog in 1852 in Transvaal gevind. ${ }^{10}$ )

Daar is in 1839 verskillende kollektelyste uitgestuur, en die eerste daarvan het gelui $\left.{ }^{11}\right)$ :

Daar des Raad des Volks besloten heeft eene Kerk op de plaats genaamd Pieter Maritz Burg, te stichten, zoo is het dan dezelve by deze een iegelijk goedgunstiglijk uitnoodigt daartoe te wille bijdragen.

Die boukommissie het bestaan uit A. W. J. Pretorius, H. P. N. Pretorius, J. S. Maritz, L. J. Meyer, J. du Plessis, J. J. Burger en J. Moolman. Op 29 Oktober 1839 skryf Sarel Cilliers vanaf Rietrivier dat die mense in $\mathrm{Natal}^{12}$ ):

alreeds een aanvang maak tot een Kerk een bereiding van Hout en Steen.

Dus hulle bou nog nie, maar kap nog hout en maak nog stene, en daarom het die boukommissie in 'n oproep wat hulle uit Pietermaritzburg gedoen het, gepraat van die kerk wat hulle "voornemens" is om te bou.

Daar was van die begin af 'n aanmerklike deel van die Voortrekkers wat teen Erasmus Smit gekant was, om redes wat hier nie ter sake is nie. In Desember 1836 wou sommiges selfs die Wesleyaanse sendeling J. Archbell in pleks van hom kies, en in Natal was daar verskillende mense wat niks met hom te doen wou hê nie, en daarom het die Volksraad op 3 Januarie 1840 besluit om die Ameri-

8) Voortrekker-Argiefstukke, bls. 70.

9) Voortrekker-Argiefstukke, bls. 84.

10) J. Stuart: De Hollandsche Afrikanen, bls. 374.

11) in Faksimilee-afdruk hiervan by A. F. Hattersley: Pietermaritzburg Panorama. p. 22.

12) G. B. A. Gerdener: Sarel Cilliers, bls. 56. 
kaanse Sendeling Lindley as predikant aan te stel mits sy dokumente in orde was, terwyl Smit wie se salaris Rks. 600 was, kon aanbly vir sy volgelinge, en op 6 Maart 1840 het hulle sy salaris tot op Rks. 800 verhoog d.w.s. van $£ 45$ tot $£ 60$.

Op 7 Maart 1840 het die Volksraad egter 'n beroep uitgebring op ds. P. K. Albertyn, 'n Afrikaander wat in die jaar 1833-1839 in Holland in die teologie gestudeer het, en teen die einde van 1839 in die Kaap terug was, waar hy op 9 Januarie 1840 as predikant gelegitimeer is. Die salaris waarvoor ds. Albertyn beroep was, was "voor de eerste jaar 100 pond steling op zijn minst," met vrye woning en 'n pensioen van Rkds. $600(=£ 45)$ per jaar as hy sou aftree, terwyl daar uitdruklik bepaal is dat Erasmus Smit ,zal als een rustend leeraar verblijfen." Die verlange na 'n perdikant was so sterk dat die mense kinderlik optimisties was dat ds. Albertyn die beroep ook sou aanneem en dadelik sou kom. Maar nou was die groot vraag, waar moet die dominee woon? 'n Pastorie was daar nie, die meeste wonings was hartbeeshuisies. Erasmus Smit het in 'n eie huis „in de lager" gewoon, d.w.s. 'n huisie wat binne die deel geleë was wat in 1839 ,van alle kanten met palen omringd" was om ,tot eene verschansing" te dien. Wat moes hulle nou aanvang as ds. Albertyn kom? Daarom het landdros J. P. Zietsman op 28 Maart 1840 aan die Volksraad as volg geskryf ${ }^{13}$ ):

\section{WelEdele Heeren,}

Een Leeraar voor deze plaatse ontboden zijnde, en welke men na alle waarschijnlijkheid met de eerste vaartuige verwagten kan. Is het ook nodig dat er voorziening voor woning en godsdienstige gestig zal worden gemaakt, omdat de tegenswoordigen niet voldoende is voor een vierde getal der gemeente te bevatten.

Heb ik goed gedagt een plan aan de Edele Raad voor te stellen welke na mijn op de voordeligste voor Kerk en gemeente op dit korte ogenblik zal komen te staan.

Uit hierdie brief van landdros Zietsman blyk dat hulle verwag het dat Albertyn die beroep sou aanneem en met die eerste skip sou kom; dat die tydelike kerkgebou, soos vroeêr gesê was dit waarskynlik 'n rietkerk, gans en al te klein; dat hy 'n plan het om aan die hand te doen waardeur die kerk en gemeente op hierdie oomblik wanneer daar nie tyd was om te verloor nie, die beste gehelp kon word, m.aw. daar was haas by die saak. Maar ongelukkig weet ons nie presies wat die plan was wat Zietsman aan die hand gedoen het nie, want in die notule van die Volksraad kom daar niks van voor nie. In elke geval weet ons dit dat daar in Aprilmaand 1840 'n publieke byeenkoms gehou is waar besluit is:

13) Natalse Argief, Landdros stukke 1840, No. 155. 
Op het Pastories grond alhier ter Plaatse een godsdienstig gestig te vervaardiegen, met welke zij eene aanvang willen neemen op Maandag den 28sten dezer - voor den verwagte leeraar den Wel Eerwaarde Heer P. Albertyn welke door den Volks Raad is beroepen voor deeze Plaats - welke gebouw na dat de kerk zal voltooijd zijn, tot een Pastorie of wooning voor den leeraar zal moeten veranderd worden.

So lui die eerste kollektelys, uitgegee op 15 April 1840, en onderteken deur J. J. Burger. Die ander lyste wat bewaar gebly het, kom daarmee, wat die inhoud anbetref, ooreen. Uit hierdie lys blyk die volgende: die publiek het besluit om op die pastorie-grond 'n godsdienstige gestig op te rig waarin ds. Albertyn moes woon en waarin ook gepreek moes word. Dit moes dus vir kerk sowel as vir pastorie diens doen, maar as die kerk klaar sou wees dan moes die geheel as pastorie vir ds. Albertyn gebruik word, en moes daar nie meer in gepreek word nie. Die benaming .godsdienstig gestig" is in die ou tyd in die Kaapkolonie sowel as deur die Voortrekkers vir 'n gebou gebruik wat kerklik van aard was, 'n kerkgebou, 'n predikantswoning of 'n plek vir kerklike samekomste. Die naam „Pastories grond" beteken gewoonweg ",kerkgrond"; die ou Hollandse benaming vir kerklike vaste eiendomme was .,pastoriegoederen." Die kerkgebou en die pastorie het gewoonlik bymekaar gelê, soms op dieselfde stuk grond, en ook aanmekaar, soos dit bv. in Wakkerstroom nog die geval was toe ds. D. P. Ackerman in 1875 daar predikant geword het, en wel so dat die eetkamer tegelykertyd ook die voordeur en die gang was waardeur die gemeente in die kerk moes kom. Sien „Die Ned. Herv. Gemeente Volksrust (Wakkerstroom) 1861-1941" deur myself, bls. 11. Hoe dit verder met hierdie planne geloop het weet ons nie, alleen dit is vas en seker: dit is nooit uitgevoer nie. Dit skyn of daar teenkanting teen hierdie planne was, want op 7 April 1840 , dus 'n week voor die kollektelyste uitgestuur is, het landdros Zietsman die volgende aan J. J. Burger geskryf, en wel aan Burger en nie aan die Volksraad nie omdat hierdie liggaam reeds op 4 April verdaag het tot 3 Junie $^{14}$ ):

Ik erken den ontvangst Uwer twede brief gedateerd 7 dezer, aandringende om eene byeenkomst op Dinsdag te mogen houden om over kerk zaken te mogen handelen. Niets kan mijn aangenamer zijn dan bijeenkomsten van dien aard mijn hoogste goedkeuring te doen weg draegen, doch ben verplicht UwEd. na de mijne van gistere te refireeren, de reeds verleende toestemming kan, nog wensch ik terug te roepen, En een twede byeenkomst over een en de zelfde onderwerp vermag ik met een gerust ge-

14) Natalse Argief, Landdros stukke 1840, No. 160. 
weeten niet permitteeren, voor en aleer men schadelijkheid daarin heb gezien, dan zoude een tweede niet kan worden geweigerd om de eerste te wederleggen - Echter vertrou ik nog UwEd. in vereeniging met de reeds gevraagde en toegestemde byeenkomst te zien, alwaar een elk het recht behoud zijn tegenwerp en de voor hem nadelige plannen te kunnen tegenspreken. - Een algemene vereenigen die ons Maatschappij in liefde band versterken zullen, is de eenigste hoop op voorspoed geluk en welvaard onzen nieuwe volksplanting.

Ds. Albertyn het die mense aan 'n lyntjie gehou en voorlopig geen besluit geneem nie, maar hulle het maar bly hoop dat hy tog nog sou kom. Op 18 Augustus 1840 het die weduwee F. Preller vanuit Kaapstad aan Generaal Pretorius geskryf dat sy 'n gerug gehoor het dat hy die beroep sou aanneem. ${ }^{15}$ ) Maar, ds. Albertyn het bedank en die mense moes nou ander planne maak. Hulle het hul weer tot Daniel Lindley gewend en hom gevra om as hul predikant op te tree, en in die Volksraadsitting van 16 Januarie 1841 het die kommissie wat sy dokumente moes ondersoek, aan die Volksraad gerapporteer dat dit alles in orde was, waarop hy op 'n salaris van $£ 100$ per jaar plus vry woning as predikant aangestel is, met ingang van 1 April, terwyl Erasmus Smit hom voorlopig moes onthou van die bediening van die sakramente. Die plan om die kerk voorlopig ook as pastorie te laat diens doen is heeltemal laat vaar, en die gebou is dan ook nooit vir so'n doel gebruik nie. Die mense het vir Lindley 'n huis of huisie gehuur ${ }^{16}$ ), en op 5 Julie 1841 het die Kerkraad besluit om die plankdak van die kerk wat gelek het, met 'n grasdak te vervang en dit van 'n paar gewels te voorsien, en binnekant 'n gallerei te bou, wat ook gedoen is. Teen die einde van 1841 het die kerkraad 'n erf tussen Lange Markstraat en Loopstraat van L. de Jager vir die som van 500 ryksdaalders gekoop en dit aan hom op 18 Januarie 1842 betaal, en op hierdie erf is ' $n$ dubbelverdieping pastorie gebou wat in 1844 voltooi is en wat gedurende verskillende jare as die pastorie van die gemeente gedien het. Lindley het toe dit klaar was daarin gaan woon ${ }^{17}$ ). Dit is dan ook een van die beste bewyse dat die kerkgebou vir 'n kerk bedoel was en nie vir 'n pastorie nie, want anders sou die mense nooit in die jare 1843-1844 'n dubbelverdieping pastorie gebou het nie. Daar bestaan dan ook nie die minste bewyse om te kan beweer dat die ou kerkie wat vandag die Voortrekker

\footnotetext{
${ }_{17}$ ) Mevr. M. de Vooght Wed. Stucki verhaal hoe sy by haar aankoms in Pietermaritz in Januarie 1847 by Lindley in die pastorie tuis gegaan het. Sien Reis en verblijf aan de Kaap en Natal, bls. 95 en 98.
} Argief.

15) Voortrekker-Argiefstukke, bls. 110

16) A short account of Mr. and Mrs. Lindley's work in South Africa. Natalse 
museum is, nie deur die Voortrekkers as die geloftekerk beskou is nie, maar wel as 'n tydelike gebou wat later deur 'n behoorlike geloftekerk vervang moes word. Wel is daar bewyse van die teenoorgestelde. So skryf Sendeling James Archbell ${ }^{18}$ ) wat baie met die Voortrekkers in aanraking was en met name met Sarel Cilliers wat hom selfs predikant van die Voortrekkers wou gehad het en wat in Hollands gepreek het $\left.{ }^{19}\right)$, in September 1841 uit Natal die volgende:

The farmers and their families are decently dressed, and, though articles of clothing at Natal are enormously expensive, they have not degenerated in their costume. Nor are they inattentive to religion. Some, it is well known, possessed more than a nominal Christianity before they left the Cape Colony; and their disasterous removel has not caused their zeal to abate. They have built a large temporary church at the Umlazi, and a more permanent one at Bushmansrands, where the Rev. Mr. Lindley is now officiating; and there, at least, the exterior of religion will be perpetuated.

Langsamerhand het daar 'n skerper skeiding gekom tussen die kerkadministrasie en die staatsadministrasie. Die kerkeiendomme is nie meer as staatseiendom beskou nie, en met die begin van 1841 het die kerkraad sy eie kasboek vir ontvangste en uitgawes aangelê. Op 7 Januarie 1842 het die Volksraad die erf waar die kerk op gestaan het, aan die kerkraad oorgemaak ${ }^{20}$ ). Maar dit was alleen die erf waar die kerk op gestaan het, en nie die erf van die markplein langsaan wat volgens die Zietsman verklaring van 1855 sou aangewys gewees het om daarop later 'n ander kerk te bou nie.

Op 6 April is die tweede eeufees van die landing van Jan van Riebeeck aan die Kaap plegtig en op godsdienstige wyse in die geloftekerk in Pietermaritzburg gevier. Die preek is deur ds. H. I.. Döhne gehou, en verder is toesprake gehou deur J. D. Marquart. J. N. Boshof en Eerw. W. Campbell ${ }^{11}$ ). In die toespraak van J. N. Boshof, die latere Vrystaatse Staatspresident, en in 1852 ouderling van Maritzburg, kom o.a. die volgende voor:

Veertien jare geleden, toen ik mij voor het eerst op reis hegal, om het land van Natal te bezien, zag ik dit geheele land land woest. onbebouwd en onbevolkt, behalwe eenige legerplaat-

18) John Bird: The Annals of Natal, I, p. 654.

19) The Diary of Dr. Andrew Smith 1834-1836 (V.R.S. 20), bls. 149, waar die skrywer verhaal hoe hy op 30 Nov. 1834 'n preek van Archbell bygewoon het wat in Hollands gehou is.

20) Volksraadsnotule, Voortrekkerwetgewing, bls. 173-174.

21) .Verrigtingen te Pietermaritzburg, Port Natal, op den 6den April 1852 ter Gedachtenis-Viering van het Tweehonder-jarig bestaan der Volkplanting De Kaap de Goede Hoop." in handskrif van 63 bladsye, in my besit. 
sen van de toen pas aangekomen Emigranten. Drie jaren daarna, toen ik mij met mijn huisgezin hier te woon kwam vestigen, werd dit Godshuis reeds opgerigt, en thans mogen wij er verscheiden andere onder tellen door Protestanten uit onze Engelsche en Schotsche medebroeders gebouwd, behalwe die door de Hollandsche Emigranten, zoo in de Souvereiniteit als over de Vaal Rivier, op verscheidene plaatsen reeds voltooid.

Let wel, met geen woord word deur Boshof, wat tog op hoogte van sake was, daarvan gerep dat hulle nog by God in die skuld gestaan het deurdat die geloftekerk nog gebou moes word.

Op 23 Julie 1853 is Generaal Andries Pretorius aan die Magaliesberg oorlede. Tien dae voor sy dood toe hy gesien het dat die einde daar was, het hy sterwende die bekende aangrypende skrywe aan die krygsraad gerig, waaronder verskeie manne was wat aanwesig was toe die gelofte afgelê is en wat aan die slag van Bloedrivier deelgeneem het. In daardie brief het hy die mense verskillende ernstige vermanings op die hart gedruk, maar 'n vermaning om die gelofte uit te voer deur die geloftekerk nou eindelik te bou, kom daar nie in voor nie. In Maart 1862 het Dewald Pretorius wat toe in die distrik Umvoti (Greytown) gewoon het, die opstel geskryf waarvan ons aan die begin melding gemaak het. Hierin sê hy die volgende oor Gelofte-dag ${ }^{22}$ ):

Dit is de dag der belofte, die verwaarloosd is. En hoe getrouw heeft de Heere niet het gebed van de bidders verhoord en de redding op het oogenbilk beschikt!

In hierdie opstel kla hy dat 16 Desember nie behoorlik gevier word nie, maar met geen enkel woord kla hy dat die belofte om 'n kerk te bou, nog nie uitgevoer is nie.

Op die Derde Natalse Ringsvergadering van Oktober 1864 wat in Pietermaritzburg gehou is, het die Kerkraad van Pietermaritzburg die volgende beskrywingspunt ingedoen :

De 16de December worde in de gemeenten Godsdienstig als cen dankdag herhacht.

Die predikant van Pietermaritzburg. Ds. P. Huet, en die afgevaardigde ouderling $\mathrm{J}$. N. Boshof, het die beskrywingspunt voorgestel en toegelig, en dit is met algemene stemme aangeneem. Hulle het op die gelofte gewys en op die nalatigheid om 16 Desember godsdienstig te vier, maar met geen enkel woord het hulle daarop selfs maar gesinspeel as sou die ander deel van die gelofte, namelik om 'n geloftekerk te bou, nog nie uitgevoer wees nie. ${ }^{23}$ ). bls. 10

22) Die genoemde brosjure „Herinnering aan de Merkwaardige Verlossing . .."

23) Notulen van de Derde Natalsche Ringsvergadering gehouden te Pieter. maritzburg 1864, bls. 10. 
In 1854 het die gedagte in die kerkraad van Maritzburg opgekom om die ou Voortrekkerkerk deur 'n ander gebou te vervang, en op 2 Oktober het diaken J. C. Boshof, 'n broer van J. N. Boshof, voorgestel ,een nieuw kerkgebouw in Pietermaritzburg te stichten." Die kerkraad het besluit om eers die gemeente hieroor te raadpleeg, upaarop daar op 9 April 1855 'n vergadering van manslidmate gehou is. Die volgende is die notule van hierdie vergadering soos dit in die kerkraadsnotuleboek voorkom:--

Deze vergadering werd te zamen geroepen door den Kerkeraad ten einde in overweging te nemen "of er een nieuwe kerk zal worden gebouwd?" Nadat de vergadering met het gebed is geopend door den Leeraar stelt hij deze vraag voor en allen er bij tegenwoordig geven een toestemmend antwoord.

Vervolgens gaat men over tot het beraadslagen over het verkrijgen van fondsen voor den opbou'w en na eenige woordenwisseling besluit de vergadering om aan den Leeraar op te dragen eene collecte in Holland te gaan ondernemen mits er een plaatsvervanger worde bezorgd, wanneer den Leeraar slechts zijn salaris zal worden gewaarborgd en geen verdere reisonkosten.

De Heeren A. de Kock, C. Kestell en Thom Martens verklaren zich tegen dit besluit.

De Heer A. de Kock stelt voor dat er eene Commissie van zeven leden zal worden benoemd om het opzicht te hebben over het bouwen der kerk; dit wordt met algemeene stemmen goedgekeurd. - Vervolgens gaat men over tot het benoemen der leden van de commissie, bij besloten stem briefjes; de Heeren T. S. Berning en P. Ferreira benoemd zijnde om die te openen zoo blijkt het dat met meerderheid van stemmen gekozen zijn de Heeren P. Ferreira, J. C. Boshcf, J. P. Zietsman, A. J. de Kock, G. J. Naude, F. S. Berning en S. v. Breda.

Men besluit dat vyf een quorum zullen uitmaken om eenig wettig besluit te kunnen nemen.

Daar word wel besluit om 'n nuwe kerk te bou, maar met geen woord word melding gemaak dat daar nog altyd 'n geloftekerk volgens belofte aan God gebou moes word. Niemand het dan ook daar getwyfel dat die bestaande kerkgebou die geloftekerk was.

Van die opdrag aan die Predikant dr. H. E. Faure om in Holland fondse te gaan insamel vir die bou van die kerk, het niks gekom nie, waarskynlik omdat die gemeente nie sy reisgeld daarheen en terug wou betaal nie. Omdat daar geen fondse voorhande was nie en die gemeente ook nie al te sterk was nie, moes planne beraam word hoe om aan die geld vir die nuwe kerk te kom. Op 2 Julie 1855 het die kerkraad die volgende besluit geneem. 
Het wordt den Leeraar opgedragen een verzoekschrift in te dienen bij het goevernement om een gedeelte van de markt ten einde eene nieuwe kerk te bouwen.

Die voorsitter van die kerkraad, dr. H. E. Fiaure, het hierop op 18 Julie die volgende versoekskrif tot die Koloniale Sekretaris gerig $\left.^{26}\right)$ :

In accordance with a resolution passed at the last meeting of Consistory of the Dutch Reformed Church I have the honour to acquaint you, for the information of $\mathrm{His}$ Honor the Acting Lieutenant Governor, that the members of our Church have it in contemplation to erect a suitable and neat place of worship in this city, as the one at present in use is altogether in a state of dilapidation; the Consistory therefore prays that $\mathrm{His}$ Honor will kindly grant them a portion of the North East end of the Market place to be appropriated for the said purpose.

The Consistory flatters itself that $\mathrm{HisHonor}$ will be inclined favourably to entertain this request, as similar grants have been made by the Government to other Dominations of Christians.

In hierdie memorie word alleen gesê dat die kerkraad 'n nuwe kerk wil bou omdat die ou gebou aan die verval was, en daar word gevra om 'n stuk van die Markplein om die nuwe kerk daarop te bou. Nòg in die kerkraadsbesluit nòg in die versoek aan die Goewerneur word ook maar met een enkel woord gemeld dat dit die grond is wat vir 'n geloftekerk opsy sou gesit gewees het, wat nou gevra word om die geloftekerk wat nog nooit sou gebou gewees het nie, op te bou. Nogmaals, van dit alles kom daar geen enkel woord van yoor nie.

Die Koloniale Sekretaris het op 23 Julie die Kerkraad geantwoord dat die Markplein die eiendom van die dorpsgemeenskap is en aan die dorp oorgedra word, sodat die waarnemende Lt. Goewerneur nie by magte is om die versoek toe te staan nie.

Dr. Faure het hom hierop na die stadsraad gewend, en op 25 Augustus 1855 die volgende versoek aan hierdie liggaam gedoen:

I herewith enclose the reply of the Local Government to a memorial of the consistory of the Dutch Reformed Church, praying for a portion of the Market Square, near the present church, as a site for a new church, and humbly request you to lay the same before the Corporation of Pietermaritzburg at its next meeting, at the same time petitioning the Corporation in the name of the Consistory o fthe Dutch Reformed Church, to grant them the said plot of ground for the above purposes.

24) Natalse Argief C.S.O. 2244, D. 140. 
Let wel, van die bou van 'n geloftekerk word niks gesê nie, netsomin as van enige aanspraak wat die kerk op die gedeelte van die markplein sou hê, deurdat die Volksraad dit in 1840 vir die bou van 'n kerk daarop sou bestem het!

Op 24 September het vier persone die volgende beëdigde verklaring gemaak ${ }^{25}$ ):

Wij onderteekenden verklaren mitz deze, ons duidelijk en goed bewust te zijn, dat het Erf naast de Kerk zijnde een gedeelte van de markt docir den Volksraad is uitgehouden voor een

Kerk. Gebouw voor de Nederduitsche Gemeente.

Wij houden ons overtuigd dat door de verwarring ontstaan bij de overgave des Lands men verzuimt heeft, om zulks by Haare Majesteits Commissaris te laten registreeren, - de bestemming van het tegenwoordig Kerk Gebouw was oorspronkelijk voor eene Pastorie.

F. C. Scheepers

Lid van den Volksraad destyds.

P. H. van Rooyen.

G. Maritz.

P. A. R. Otto.

Declared before me the 24th September 1855

Geo. Macleroy, J.P.

En 4 Oktober het J. P. Zietsman die volgende verklaring gemaak wat 'n dag later beëdig is $^{26}$ ):

I John Philip Zietsman do hereby declare that in 1840 being then the Landdrost at this place under the Volks Raad was requested by a building committee to join them to select a place for the erection of a temporary place of worship, which was fixed where the present Dutch Reformed Church now stand. The present building was erected to be used as a temporary church, and to be altered afterwards when more funds in hand to build a proper Church for a parsonage, with the extend of a full Erf. $\mathrm{O}$ a my request then where they was intended to build the proper Church they spoke of to build thereafter. The next ground on the present Market Square was pointed out to me, to which I gave my consent and was afterwards approved of by the Volks Raad in their first sitting.

The reason why that piece of land for the intended Church was not registered with Her Majesty's Commissioner I cannot say other than on account of confusion then existed under the

25) Natalse Argief C.S.O. 2244, D. 268.

26) Natalse Argief C.S.O. 2244, D. 268. 
Volks Raad as well as under the public.

Pietermaritzburg.

October 4th. 1855.

J. P. Zietsman.

Declared before me this 5th. day of October 1855.

John Bird, J.P.

In verband met hierdie twee verklarings moet die volgende opgemerk word:-

le. In Zietsman se verklaring moet onder die "first sitting" van die Volksraad nie verstaan word die eerste sitting wat hierdie liggaam op Maritzburg gehou het nie, maar die eerste sitting nadat die Volksraad die versoek sou ,approved" het. ${ }^{27}$ ).

2e. Die vergadering van die boukommissie was die vergadering wat in April 1840 plaasgevind het toe daar, soos ons gesien het, onenigheid oor die saak was tussen Burger en Zietsman.

3e. In geen van hierdie verklarings word ook maar met een enkele woord gesê dat die Volksraad in 1840 die betrokke stuk grond spesiaal vir die geloftekerk as 'n soort van .,geloftegrond" afgesonder het nie.

4e. In die bestaande volksraadsnotule kom geen enkel woord oor die saak voor nie.

5e. In die verklaring van Zietsman word gesê dat die deel van die Markplein wat in 1840 deur die Volksraad bestem sou gewees het om $n$ kerk daarop te bou. nie op naam van die kerk geregistreer is nie, omdat daar deur die koms van die Engelse kommissaris $\mathrm{H}$. Cloete ' $n$ verwarring onder die Volksraad sowel as onder die publiek ontstaan het. Maar Cloete het eers in 1843 in Natal aangekom, terwyl die Volksraad reeds op 7 Januarie 1842, soos ons gesien het, die kerkerf aan die kerk oorgemaak het; en die vraag kom by mens op, waarom dan ook nie op 7 Januarie 1842, meer as 'n jaar voor die koms van Cloete, die erf van die Markplein wat vir die bou van 'n kerk bestem sou gewees het?

6e. Een van die persone wat die verklaring gemaak het, nl. P. H. van Rooyen, was ook lid van die kerkraad, en hy was aanwesig op die vergadering van 2 Julie 1855 toe besluit is om aansoek te doen om 'n deel van die Markplein, maar toe is met geen woord gerep van enige aanspraak wat die kerkraad op daardie grond sou hê nie. Waar om het hy die kerkraad toe nie van die aanspraak verwittig nie?

${ }^{27)}$ Die eerste sitting van die Volksraad op Pietermaritzburg was in elk geval voor 19 Mei 1839, sien die Volksraadsnotule, "Voortrekker Wetgewing" bls. 1, terwyl Zietsman eers op 3 Januarie 1840 landdros geword het, Voortrekker Wetgewing bls. 29 . Verder het C. F. Scheepers, wat verklaar het dat hy destyds volksraadslid was en hom die saak goed onthou, eers op 4 Maart 1840 volksraadslid geword het, en 'n verklaring wat hy in 1852 gedoen het, het hy eers op 1 Julie 1839 in Natal aangekom, sien Proceedings of the Commission appointed to enquire into the past and the present state of the Kafirs in the District of Natal Part I (1852), p. 46. 
En as die twee verklarings korrek is, dan kom die volgende vrae onwillekeurig by mens op:

le. As dit in 1840 die bedoeling was om die kerk op die erf wat gedeelte van die markplein is, te bou, en die pastorie op die grond waar die ou kerk op staan, waarom het die Kerkraad dan in hulle armoede in 1841 'n ander erf van 50 Ryksdaalders gekoop om die pastorie daar te bou?

2e. Waarom het die Volksraad dan op 7 Januarie 1842 alleen Jie erf waar die kerkgebou op gestaan het, aan die kerk afgestaan, en ook nie die erf wat volgens die Zietsman-verklaring aan die kerk sou beloof gewees het?

3e. Is die huidige kerkgebou wat die gemeente in 1855 besluit het om te bou, en wat op 7 April 1861 ingewy is, dan nie die regte geloftekerk nie? Want dit het dan tog die "temporary church" vervang en is in daardie dae as 'n baie waardige en sierlike gebou beskou. ${ }^{28}$ )

Die versoek van dr. Faure namens die kerkraad het op 5 September 1855 voor die stadsraad gekom. ${ }^{29}$ ) En toe eers het J. C. Boshof daarvan melding gemaak dat die Volksraad in 1840 die betrokke deel van die Markplein vir die bou van 'n kerk sou bestem het. Boshof was ook diaken, en was aanwesig in die kerkraadsvergadering van 2 Julie 1855 toe besluit is om applikasie te mak vir 'n deel van die Markplein om 'n kerk daar te bou, maar toe het hy niks van die vermeende Volksraadsbesluit gesê nie. Die Stadsraad het nog 'n keer hieroor vergader, en op 15 Desember 1855 het die stadsklerk die volgende antwoord aan dr. Faure gestuur:

I have the honour to acknowledge the receipt of your Memorial dated August 28th 1855, on behalf of the Consistory of the Dutch Reformed Church applying for the grant of a plot of ground on the Market Square for the purpose of erecting a Church, and to inform you in reply, that by a resolution passed by the Town Council at a Special Meeting held on the 18th instant, it was decided "that the Council is of opinion, that the

${ }^{28}$ ) In die Kerkbode van 18 Mei 1861, bls. 158-160, kom 'n verslag van die inwydingsplegtigheid voor, en daarin word die volgende beskrywing van die nuwe kerk gegee: „Het is een hoogst bevallig gebouw, dat aan het einde van de groote markt geplaatst, met zijn gothiese ramen en spitsen toren tegen de omringende groene heuvels een sierlijke vertooning maakt. Ook het inwendig, zoowel wat predikstoel, galerij, banken betreft, laat niets te wenschen over. Wij hebben den Heer te danken, die ons zulk eene lieflijke plaats der zamenkomst heeft geschonken. (Ps. CXXVII:2)" By die inwyding was o.a. die Goewerneur en die Hoofregter ook aanwesig. In daardie dae was daar nêrens in Transvaal of Vrystaat so ' $n$ mooi kerkgebou, en in die Kaapkolonie was maar 'n paar kerke wat mooier was. As die mense sou gedink het dat die ou kerk nie waardig of sierlik genoeg vir 'n geloftekerk was nie, dan sou hulle dit van hierdie nuwe kerk seer seker nie kon gedink het nie.

29) The Natal Witness, 7 Sept. 1855. 
Dutch Reformed Church is equitably entitled to the Erf applied for, but that owing to legal impediments arinsing through the latches of the applicants, it is found impossible for the Council to entertain their Memorial."

Hierop het dr. Faure op 17 Desember die volgende skrywe aan die Koloniale Sekretaris gerig ${ }^{30}$ ):

I herewith beg to transmit to you the answer of the Town Council of Pietermaritzburg to a memorial of the Dutch Reformed Church praying for a site on the Market Square to build a church upon and I humbly request you, in the name of our Consistory, to lay the same before His Honor the Acting Lieutenant Governor together with the accompanying documents on which the opinion of the Council of Pietermaritzburg is based. The Consistory willingly admits that through the mismanagement and neglect of its former office-bearers who omitted the proper registration of the erf with Her Majesty's Commissioner for the time being, all legal claim to the ground has been lost to the Dutch Reformed Church, but as the Government has frequently overlooked such neglect on the part of private individuals and notwithstanding their omission restored to them their land they laid claim to, the Consistory of the Dutch Reformed Church humbly trusts and prays that $\mathrm{His}$ Honor will be disposed to use the same clemency to a public body and restore to the Dutch Church such a portion of the said erf adjoining the present Church as will be sufficient to build a Church upon.

The Consistory feels sure that, with the affidavits of gentlemen so highly esteemed as those who have affixed their signatures, who moreover had the very best opportunity of knowing all the merits of the case, His Honor will be perfectly satisfied, as were the members of the Town Council "that the Dutch Church is equally entitled to the erf" and the Consistory therefore prays that His Honor will be pleased to have such a portion of the same registered in the name of the Consistory as $\mathrm{His}$ Honor will be pleased to restore to the Dutch Church. volg :

Op 19 Desember 1855 antwoord die Koloniale Sekretaris as

The land prayed for has been alienated by the Crown in favour of the Corporation of Pietermaritzburg in trust for the inhabitants of the Borough. The power of the local Govt. to deal with the land in question having consequently ceased, Memt. is informed that the Acting Lt. Governor is unable to interfere in this matter.

30) Die korrespondensie is te vinde in die Natalse Argief C.S.O. 224, D. 268 , 275 en S.G.O. $11 / 5 / 15$. 
Dr. Faure het op 26 Desember aan die Koloniale Sekretaris teruggeskryf :-

In reply to your letter of the 19th inst.. I have to request you to state to His Honor the Acting Lieutenant Governor, that the Consistory of the Dutch Reformed Church sincerely regrets that His Honor considers himself unable to interfere in this matter. as the land prayed for has been alienated by the Crown in favour of the Corporation of Pietermaritz Burg, though from these very words the Consistory feels assured that Her Majesty's Representative is perfectly prepared to interfere in behalf of our Church, when such is within His power, - the Consistory therefore prays, that His Honor will be pleased to grant a site to the Dutch Reformed Church in the centre of the land reserved by the Government on the Commerical Road opposite the Market Square. either as a compensation for the if to which the Dutch Church is equitalby entitled to the opinion of the present holders thereof, or as a Government Grant to the Dutch Church. In case His Honor cannot give the land applied for as a compensation, the Consistory humbly trusts that His Honor will not scruple to transfer it to the same as a grant, seeing that portions of the same land have already been granted by the Government to two dominations of Christians for a similar purpose.

Die aanmerking van die Goewerneur hierop was as volg:-

The Lieut. Governor is unable to grant the request; His Honor is however quite prepared to grant 2000 acres of land in the country as an endowment for the Church in question provided the Consistory are able to provide for themselves by purchase or otherwise the necessary site: the land to be selected as soos as possible must be free from local objection.

En die Koloniale Sekretaris se antwoord aan dr. Faure, gedateer 17 Januarie 1856 :

It is out of the Act. Lt.'s power to comply with the prayer of Memt. His Honor is prepared however to grant as an endowment to the Dutch Reformed Church an extent of 2000 acres of land in the country, to the grant of which no local objection may exist, provided the Consistory are able to obtain, by purchase or otherwise, the requisite site for their Church in this Town.

Op 18 Julie het dr. Faure weer aan die Koloniale Sekretaris geskryf :

Wit reference to your letter dated 17th January 1856 informing me that "His Honor is prepared to grant as an endowment to the Dutch Reformed Church an extent of 2000 acres of land in the Country," I beg you will apply to His Honor the Acting Lieutenant Governor, on behalf of the Consistory of the Dutch 
Reformed Church of Pietermaritzburg, that His Honor may be pleased to grant to them Lot No. 50 on the Government Map of this Country and cause the same to be issued to the Consistory of the Dutch Reformed Church of Pietermaritzburg.

Hierop het die Koloniale Sekretaris op 23 Julie 1856 die volgende aan die Kerkraad geskryf :

The Acting Lieut. Govr. has been pleased to comply with the prayer of Memt., and has instructed the Surveyer Genl. to prepare a Title to the land prayed for in favour of the Consistory of the D. R. Church.

Die kerkraad het in sy vergadering van 4 Augustus 1856 waar behalwe dr. Faure ook nog G. J. Naude, T. J. Nel, P. Ferreira, P. H. van Rooyen, J. P. Zietsman en J. N. Boshof aanwesig was, die saak behandel. In die notule kom die volgende voor:

De leeraar deelt mede dat het Gouvernement er toe is overgegaan om aan de Nederduitsch Gereformeerde Kerk van Pietermaritzburg een stuk grond achter den Zwartkop ter groote van 1885 akkers te geven ter vergoeding van het erf op de openbare markt naast de Kerk oorspronkelijk voor het bouwen eener kerk door den Volksraad ingehouden; dit wordt met blijdschap en dankbaarheid vernomen.

\section{BEVINDings.}

1. In 1839 is 'n voorlopige rietkerk gebou.

2. In 1840 is aanstalte gemaak met die bou van die permanente kerk, en hoewel daar met die beroep van ds. Albertyn sprake was om die kerk so te bou dat dit uiteindelik as pastorie gebruik kan word en die eintlike kerk op 'n ander plek te bou, is hierdie gedagte nooit uitgevoer nie, maar is die gebou as 'n kerk gebou. Die verklaring van Zietsman en Scheepers c.s. is in 1855 berus waarskynlik hierop dat hulle later gemeen het dat die Volksraad in 1840 die planne om die kerk later in 'n pastorie te verander, goedgekeur het. So 'n vergissing is bes moontlik.

3. Die kerk is van 1841-1861 as kerk gebruik, en eers toe dit begin verval het, deur 'n ander kerk vervang.

4. In 1843-1844 is 'n pastorie gebou, wat jare lank as sodanig gebruik is.

5. Die kerk wat in 1840-41 gebou is, is altyd as die kerk beskou wat gebou is ten gevolge van die gelofte. Nie alleen deut die Afrikaanders is dit so beskou nie, maar ook deur die 
Engelse, en as bewyse hiervoor word na die volgende verwys :-

(a) John Noble: South Africa, Past and Present (1877) maak op bladsy 93 melding van die gelofte, en sê dan-

The Dutch Reformed Church was one of the first buildings erected at Pietermaritzburg, in fulfilment of this solemn undertaking.

(b) D. F. C. Moodie: The History of Battles and adventures etc. (1888) Vol. I, p. 436 (Australiese uitgawe p. 166)Chaarl Cilliers was for many years an elder of the Dutch Reformed Church at Pietermaritzburg which he and others of the primitive boers erected as a memorial of the gracious Providence which crowned their arms with victory on the occasion of the battle with Dingaan in 1838.

(c) Robert Russell, superintendent van Onderwys in Natal, het in 1891 'n boek gepubliseer "Natal the Land and its story: A Geography and History for the use of Schools," en op bls. 159 sê hy in verband met die gelofte: The vow made before the battle was religiously kept. The Dutch Reformed Church in Martizburg - one of the first buildings in the town - was erected in fulfilment of the solemn pledge; and Dingaan's Day, the 16th. of December, is still observed by all Dutch people in South Africa as a holy anniversary.

(d) Forseyt Ingram: The Colony of Natal (1895) bls. 174175:

At the foot of the Market Skuare stands an old building, now used as a soda-water factory. This was the first church and one of the first houses erected in Pietermaritzburg, and the, circumstances connected with its erection are worth narrating.

The Weenen massacre had inspired in the Boer emigrants a deep desire for revenge, and their own safety to great extent depended upon the overthrow of Dingaan and his forces. An expedition was organised for this object, and proceeded against the Zulu chief; but before making any attack upon him, the Boers engaged in prayer, and made a solemn vow that if the Lord would grant them the victory, they would "raise a house to the memory of $\mathrm{His}$ great name, wherever it might please Him." Needless to say, decisive victory blessed their arms, and the vow was 
faithfully kept by the erection of the old Dutch Church above referred to, and every man of this party assisted either with labour or materials. This is the Mother Church of South East Africa.

(e) J. Forsyth Ingram: The Story of an African City (1898) op bls. 22 maak hy melding van die gelofte, en sê op bls. 24:

The Voortrekkers had kept their covenant, and built

a house of worship to the honour and glory of God.

(f) G. McCall Theal: History of the Boers in South Africa (1887) bls. 241:

The church at Pietermaritzburg stands as a sign that they kept their vow.

6. As die kerkraad van Pietermaritzburg enige regte en aansprake had op ' $n$ deel van die Markplein om daar 'n kerk te bou, dan blyk dit uit niks dat dit vir 'n geloftekerk was nie, en dan het die kerkraad in 1856 hierdie aanspraak verruil vir die stuk grond agter die Zwartkop.

My vaste oortuiging is dat die Voortrekkers die gelofte uitgevoer het en die geloftekerk gebou het, sodat daar geen blaam of klad op hul nagedagtenis rus nie.

S. P. Engelbrecht. 